\title{
Histomorphological Study of Salivary Gland Tumours
}

\section{IJCRR}

Section: Healthcare

Sci. Journal Impact

Factor: 6.1 (2018)

ICV: 90.90 (2018)

(c) (i) (3)

Copyright@IJCRR

\section{Reena Banerjee $^{1}$, R. K. Chandrakar ${ }^{2}$}

'Associate Professor Dept. of Pathology Chandulal Chandrakar Memorial Medical College, Kachandur, Durg, Chhattisgarh, India; ${ }^{2}$ Associate Professor Dept. of Pathology Chandulal Chandrakar Memorial Medical College, Kachandur, Durg, Chhattisgarh, India.

\section{ABSTRACT}

Introduction: Tomours of the salivary glands are an uncommon phenomenon. A heterogeneous community of pathologies includes around 3-10\% of carcinomas of the head and neck and just $0.5 \%$ of all malignant tumours suit these forms. Although most other cancers of the head and neck are closely linked to smoking and alcohol, the salivary glands do not play a role in these. Some studies have found that a diet rich in vitamin C and low in cholesterol can help prevent salivary cancer of the gland. An increased risk of salivary gland cancers was found to be associated with HIV infection.

Objective: To identify different salivary gland histomorphological trends tomours, age, frequency and distribution of sites.

Material \& Methods: Present study was at Chandulal Chandrakar Memorial Medical College and hospital. A total of 63 samples were studied. Demographic information was collected with information on location of tumor and size of tumor was determined for each salivary gland tumor. In both major and minor glands of malignant salivary gland tomours, frequency of benign and malignant tumor was determined.

Results: There were total 23 malignant tumor and 40 benign tomours. It has been observed that out of total 23 malignant tomours, $17(73.9 \%)$ were parotid glands, $4(17.4 \%)$ were submandibular glands while $2(8.7 \%)$ were minor salivary gland. Among mucoepidermoid carcinoma, the parotid gland was found to be most common $(\mathrm{N}=8,34.8 \%)$. Among all 40 benign tumours, $1(2.5 \%)$ was minor salivary gland, $5(12.5 \%)$ were submandibular gland and $34(85 \%)$ parotid glands. In warthins tumour $(\mathrm{N}=9$, $22.5 \%)$ and pleomorphic adenoma $(\mathrm{N}=13,32.5 \%)$ parotid gland was more frequent compared to minor salivary gland and submandibular gland.

Conclusion: The most common carcinoma of mucoepidermoid is widely known malignant tumour of the parotid and salivary glands is a common site to the same. The histopathological checkup is mandatory for salivary gland tumour diagnosis as they occur to have a vast range of morphological patterns.

Key Words: Malignant, Tumour, Salivary glands, Carcinomas, Heterogeneous community

\section{INTRODUCTION}

Tumours of the salivary glands are an uncommon phenomenon. A heterogeneous community of pathologies includes around $3-10 \%$ of carcinomas of the head and neck and just $0.5 \%$ of all malignant tomours suit these forms ${ }^{1}, 2$. Annually around $0.4-13.5$ per 1 lakh population are affected by salivary gland tomours globally ${ }^{3,4,5}$. The etiologic causes of cancers of the salivary gland remain unknown. Although most other cancers of the head and neck are closely linked to smoking and alcohol, the salivary glands do not play a role in these. Some studies have found that a diet rich in vitamin $\mathrm{C}$ and low in cholesterol can help prevent salivary cancer of the gland ${ }^{6}$. There is equal distribution of salivary gland cancers in both sexes and generally occurs in sixth decade of life ${ }^{7}$.

History of prior cancers linked to Epstein-Barr virus, immunosuppression and radiation was also associated with an increased risk of cancer of the salivary glands. The risk of salivary gland cancer for Hodgkin's lymphoma patients was increased four-folds as reported in a Swedish study ${ }^{8}$. Both major and minor salivary glands are affected of which $80 \%$ of the tumour are seen in parotid gland while most minor tumours are located in the palate 9 . The smaller the salivary gland is, the more likely the tumour is malignant,

\section{Corresponding Author:}

Dr. R. K. Chandrakar, Associate Professor Dept. of Pathology, Chandulal Chandrakar Memorial Medical College, Kachandur, Durg, Chhattisgarh, 490024, India; Email: ambad.sawan@gmail.com

ISSN: 2231-2196 (Print) ISSN: 0975-5241 (Online)

Received: 15.06.2020

Revised: 08.07.2020

Accepted: 12.08 .2020

Published: 22.08 .2020 
$20-25 \%$ of tumours in the parotid glands are malignant. Of the submandibular glands, this increases to $40 \%$, and more than $90 \%$ of sublingual gland tumours are malignant ${ }^{10,11}$. An increased risk of salivary gland cancers was found to be associated with HIV infection ${ }^{11}$.

Tumours of the salivary glands may be shocking Morphological diversity vary among different types of tumours and even inside a single mass of tumours. So, it is important to identify various histomorphological patterns and classify them accordingly. The objectives of the present study were to identify different salivary gland histomorphological trends tomours, age, frequency and distribution of sites.

\section{MATERIAL \& METHODS}

The present study was at Chandulal Chandrakar Memorial Medical College and hospital. A total of 63 samples were studied. Demographic information was collected with information on the location of the tumour and the size of the tumour was determined for each salivary gland tumour. In both major and minor glands of malignant salivary gland tumours, frequency of benign and malignant tumour was determined. The specimens for biopsy were fixed in $10 \%$ formalin where they were further processed into paraffin-embedded sections and stained with hematoxylin and eosin (HE). The classification of histopathology of all tumours was done according to the World Health Organization (WHO) histological typing of salivary glands.

\section{RESULTS}

Table 1: Gender wise distribution of salivary gland tomours and their site

\begin{tabular}{|c|c|c|c|c|c|c|c|}
\hline \multirow[t]{2}{*}{ Sex } & \multicolumn{2}{|c|}{ Minor Salivary gland } & \multicolumn{2}{|c|}{ Submandibular gland } & \multicolumn{2}{|c|}{ Parotid gland } & \multirow[t]{2}{*}{ Total } \\
\hline & Benign & Malignant & Benign & Malignant & Benign & Malignant & \\
\hline Female & 1 & 1 & 2 & 3 & 12 & 6 & 25 \\
\hline Male & o & 1 & 3 & 1 & 22 & 11 & 38 \\
\hline
\end{tabular}

Table no 1 Showed: there were 25 females and 38 males included in this study.

Table 2: Distribution of salivary gland tomours according to age

\begin{tabular}{llll}
$\begin{array}{l}\text { Age groups (in } \\
\text { years) }\end{array}$ & $\begin{array}{l}\text { Malignant } \\
\text { Tumor }\end{array}$ & $\begin{array}{l}\text { Benign } \\
\text { Tumor }\end{array}$ & $\begin{array}{l}\text { Total no. of } \\
\text { cases }\end{array}$ \\
\hline$<20$ & 1 & 4 & 5 \\
$21-40$ & 4 & 9 & 13 \\
$41-60$ & 10 & 14 & 24 \\
$61-80$ & 6 & 10 & 16 \\
$>80$ & 2 & 3 & 5 \\
Total & 23 & 40 & 63 \\
\hline
\end{tabular}

Table no 2 shows It was observed that the cases ranged from 13 years to 81 years with a mean age of 45.2 years. A maximum number of malignant cases was found in the age group 41-60 years followed by $61-80$ years. A benign tumour was common in the age group of 41-60 years. There were a total of 23 malignant tumours and 40 benign tumours.
Table 3: Distribution of malignant tumour in salivary glands.

\begin{tabular}{|c|c|c|c|c|}
\hline Type of tumour & $\begin{array}{l}\text { Minor sali- } \\
\text { vary gland }\end{array}$ & $\begin{array}{l}\text { Subman- } \\
\text { dibular } \\
\text { gland }\end{array}$ & $\begin{array}{l}\text { Parotid } \\
\text { gland }\end{array}$ & Total \\
\hline $\begin{array}{l}\text { Polymorphous } \\
\text { low-grade adenocar- } \\
\text { cinoma }\end{array}$ & o & o & o & o \\
\hline $\begin{array}{l}\text { Acinic cell carci- } \\
\text { noma }\end{array}$ & o & o & o & o \\
\hline $\begin{array}{l}\text { Metastatic undiffer- } \\
\text { entiated carcinoma }\end{array}$ & o & o & o & o \\
\hline $\begin{array}{l}\text { Squamous cell car- } \\
\text { cinoma }\end{array}$ & o & o & o & o \\
\hline Basal cell carcinoma & o & o & 1 & 1 \\
\hline $\begin{array}{l}\text { Unclassified malig- } \\
\text { nant tumor }\end{array}$ & o & o & 1 & 1 \\
\hline $\begin{array}{l}\text { Adenocarcinoma } \\
\text { NOS }\end{array}$ & o & o & 1 & 1 \\
\hline $\begin{array}{l}\text { Carcinoma Eex- ple- } \\
\text { omorphic adenoma }\end{array}$ & o & 1 & 2 & 3 \\
\hline $\begin{array}{l}\text { Adenoid cystic } \\
\text { carcinoma }\end{array}$ & 1 & 1 & 4 & 6 \\
\hline $\begin{array}{l}\text { Mucoepidemoid } \\
\text { carcinoma }\end{array}$ & 1 & 2 & 8 & 11 \\
\hline Total & 2 & 4 & 17 & 23 \\
\hline
\end{tabular}


Table no 3 shows: It has been observed that out of total 23 malignant tumours, $17(73.9 \%)$ were parotid glands, $4(17.4 \%)$ were submandibular glands while $2(8.7 \%)$ were minor salivary gland. Among mucoepidermoid carcinoma, the parotid gland was found to be most common $(\mathrm{N}=8,34.8 \%)$.

\begin{tabular}{|c|c|c|c|c|}
\hline Type of tumor & $\begin{array}{l}\text { Minor } \\
\text { salivary } \\
\text { gland }\end{array}$ & $\begin{array}{l}\text { Submandibu- } \\
\text { lar gland }\end{array}$ & $\begin{array}{l}\text { Parotid } \\
\text { gland }\end{array}$ & Total \\
\hline Lipoma & o & o & o & o \\
\hline Schwannoma & o & o & 1 & 1 \\
\hline Basal cell adenoma & o & o & 3 & 3 \\
\hline Myoeithelioma & o & o & 3 & 3 \\
\hline $\begin{array}{l}\text { Monomorphic } \\
\text { adenoma }\end{array}$ & o & 1 & 5 & 6 \\
\hline Warthins tumor & o & 2 & 9 & 11 \\
\hline $\begin{array}{l}\text { Pleomorphic } \\
\text { adenoma }\end{array}$ & 1 & 2 & 13 & 16 \\
\hline Total & 1 & 5 & 34 & 40 \\
\hline
\end{tabular}

Among all 40 benign tumours, 1(2.5\%) was minor salivary gland, 5(12.5\%) were submandibular gland and 34(85\%) parotid glands. In warthins tumour $(\mathrm{N}=9,22.5 \%)$ and pleomorphic adenoma $(\mathrm{N}=13,32.5 \%)$ parotid gland was more frequent compared to minor salivary gland and submandibular gland.

\section{DISCUSSION}

The etiologic causes of cancers of the salivary gland remain unknown. Whereas most other cancers of the head and neck are closely linked to smoking and alcohol, the salivary glands do not play a role in these. Some studies have found that a diet rich in vitamin $\mathrm{C}$ and low in cholesterol can help prevent salivary cancer of the gland. The most common form overall for the malignant salivary tumour is mucoepidermoid carcinoma. In the present study parotid was the most frequent site of cancer $80.9 \%$ in agreement with the study done by Amin NS et. Al. which reported parotid as most common $77.1 \%$. Parotid was followed by the submandibular gland (14.3\%) in our study compared to $17.7 \%$ in the study by Amin NS et al. ${ }^{12}$ whereas the minor salivary gland was the least common site noted at $4.78 \%$ in our study.

In this study, the mucoepidermoid carcinoma was the most common malignant salivary gland tumour constituting $36.5 \%$ cases $(\mathrm{N}=23)$ which is similar to study of the histomorphological spectrum of salivary gland reporting $36.1 \%$ of cases $^{5,12}$. The commonest type overall is mucoepidermoid carcinoma for malignant salivary tumour. However, if in turn each salivary gland is looked upon, it can be seen that mucoepidermoid carcinoma is the only commonest cancer in the parotid glands comprising about $33 \%$ as shown in some studies ${ }^{13},{ }^{14}$. In our study mucoepidermoid carcinoma in parotid gland was found to be most common $(\mathrm{N}=8,34.8 \%)$. A large number of malignant cases were observed in the fourth decade followed by the Fifth decade in the present study. A study by Chatterjee et al. and Amin NS reported a large number of malignant cases in $3^{\text {rd }}$ decade followed by the fourth decade ${ }^{12,15}$. Tumours with salivary glands may display a remarkable range of Morphological variation of the various types of tumours and even within the mass of a single tumour. In such instances, they are hard to accurately identify on histopathological grounds only.

\section{CONCLUSION}

Tumours of the salivary gland are extremely rare. Benign salivary Gland tumours are more commonly identified than malignant ones. The Parotid gland is the most frequent site for the development of tomours in the salivary gland. Adenoma with pleomorphic impact is the tumour detected most commonly in all salivary gland tomours. The most common carcinoma of mucoepidermoid is widely known malignant tumour of the parotid and salivary glands is a common site to the same. A histopathological checkup is mandatory for salivary gland tumour diagnosis as they occur to have a vast range of morphological patterns.

\section{Acknowledgement: Nil}

\section{Conflict of Interest: Nil}

Source of Funding: Nil

\section{REFERENCES}

1. Jones AV, Craig GT, Speight PM, Franklin CD. The range and demographics of salivary gland tomours diagnosed in a UK population. Oral Oncol 2008; 44:407-17.

2. Lawal AO, Adisa AO, Kolude B, Adeyemi BF.Malignant salivary gland tumours of the head and neck region: a single institutions review. Pan Afr Med J. 2015; 20:121.

3. Ma'aita JK, Al-Kaisi N, Al-Tamimi S, and Wraikat A. Salivary gland tomours in Jordan: a retrospective study of 221 patients. Croat Med J 1999;40:539-42

4. Tian Z, Li L, Wang L, Hu Y, and Li J. Salivary gland neoplasms in oral and maxillofacial regions: a 23 -year retrospective study of 6982 cases in an eastern Chinese population. Int J Oral Maxillofac Surg 2010;39:235-42

5. Pratibha Dawande, Neha Bhatt, Obaid Noman, Sweta Bahadure, Arvind Bhake. Corelation Between Cytological and Histological Grading of Breast Cancer and its Utility in Patient's Management. International Journal of Current Research and Review. Modern Therapeutics Applications, July, 2020, 71-76

6. Horn-Ross PL, Morrow M, Ljung BM. Diet and the risk of salivary gland cancer. Am J Epidemiol. 1997 Jul 15; 146(2):171-6.

7. Licitra L, Grandi C, Prott FJ, Schornagel JH, Bruzzi P, Molinari R. Major and minor salivary glands tumours. Crit Rev Oncol Hematol. 2003 Feb; 45(2):215-25. 
8. Dong C, Hemminki K. Second primary neoplasms among 53 159 haematolymphoproliferative malignancy patients in Sweden, 1958-1996: a search for common mechanisms. Br J Cancer. 2001 Sep 28; 85(7):997-1005.

9. Speight PM, Barrett AW. Salivary gland tumours. Oral Dis. 2002 Sep; 8(5):229-40.

10. Loyola AM, de Araújo VC, de Sousa SO, de Araújo NS. Minor salivary gland tumours. A retrospective study of 164 cases in a Brazilian population. Eur J Cancer B Oral Oncol. 1995 May; 31B(3):197-201.

11. Meghavi R. Joshi, Dhaval Jetly, Mital Kundariya. The Malignant Round Cell Tomours: Histopathological Study and Immunohistochemistry. International Journal of Current Research and Review. Vol 11 Issue 08, April, 01-07
12. Amin NS, Shah SA, Prajapati SG, Goswami HM. Histomorphological spectrum of salivary gland tomours in a tertiary care hospital - A retrospective study. Int J Med Sci Public Health 2017;6:299-302

13. Lukšić I, Virag M, Manojlović S, Macan D. Salivary gland tumours: 25 years of experience from a single institution in Croatia. J Craniomaxillofac Surg. 2012 Apr; 40(3):e75-81.

14. Agulnik M, McGann C, Mittal B, Gordon S, Epstein J. Management of salivary gland malignancies: current and developing therapies. Oncology Reviews. 2008;2(2):86-94.

15. Chatterjee MT and Panda PK. A Pathological study of benign and malignant tomours of salivary glands; MJAFI 2000; 56:2826. 